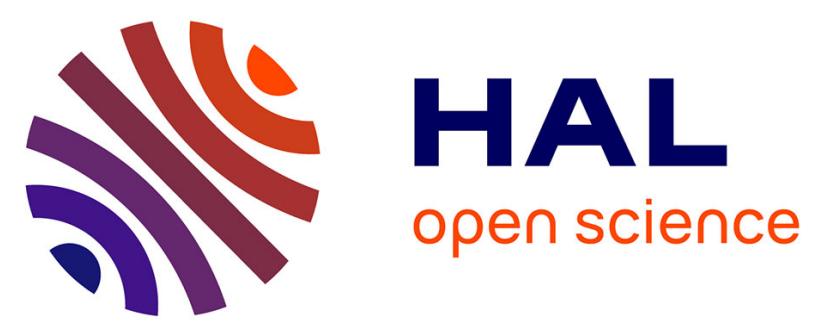

\title{
Syndepositional cements associated with nannofossils in the Marmolada Massif: Evidences of microbially mediated primary marine cements? (Middle Triassic, Dolomites, Italy)
}

\author{
Franco Russo, Pascale Gautret, A. Mastandrea, Edoardo Perri
}

\section{To cite this version:}

Franco Russo, Pascale Gautret, A. Mastandrea, Edoardo Perri. Syndepositional cements associated with nannofossils in the Marmolada Massif: Evidences of microbially mediated primary marine cements? (Middle Triassic, Dolomites, Italy). Sedimentary Geology, 2006, 185, pp.267-275. 10.1016/j.sedgeo.2005.12.017 . hal-00091728

\section{HAL Id: hal-00091728 \\ https://hal-insu.archives-ouvertes.fr/hal-00091728}

Submitted on 19 Sep 2006

HAL is a multi-disciplinary open access archive for the deposit and dissemination of scientific research documents, whether they are published or not. The documents may come from teaching and research institutions in France or abroad, or from public or private research centers.
L'archive ouverte pluridisciplinaire HAL, est destinée au dépôt et à la diffusion de documents scientifiques de niveau recherche, publiés ou non, émanant des établissements d'enseignement et de recherche français ou étrangers, des laboratoires publics ou privés. 


\title{
Syndepositional cements associated with nannofossils in the Marmolada Massif: Evidences of microbially mediated primary marine cements? (Middle Triassic, Dolomites, Italy)
}

\author{
Franco Russo ${ }^{a}$, Pascale Gautret $^{\mathrm{b}}$, Adelaide Mastandrea ${ }^{\mathrm{a}}$ and Edoardo Perri ${ }^{\mathrm{a}}$ \\ ${ }^{\mathrm{a} D i p a r t i m e n t o ~ d i ~ S c i e n z e ~ d e l l a ~ T e r r a, ~ U n i v e r s i t a ̀ ~ d e l l a ~ C a l a b r i a, ~ P o n t e ~ B u c c i, ~ c u b o ~ 15 b, ~} 87036$ \\ Rende (CS), Italy \\ ${ }^{\mathrm{b}}$ Institut des Sciences de la Terre d'Orléans, (ISTO), UMR 6113 CNRS, Université d'Orléans, \\ F-45067 Orléans Cedex 2, France
}

\section{Abstract}

The Marmolada platform is characterized by striking globose masses ("evinosponges"), arranged in concentric bands, of fibrous calcite cements ranging in size from centimeters to several decimeters. The lithogenetic importance of these peculiar cements has been recognized in many Middle Triassic buildups of the Western Tethys. EDS microanalyses revealed that these fibrous cements contain 1-3 $\mathrm{mol} \%$ of $\mathrm{Mg}$ and detectable amounts of $\mathrm{Sr}$, over $1000 \mathrm{ppm}$, sometimes exceeding 10,000 ppm. The strontium geochemical signature in neomorphic calcite could reflect the replacement of an aragonitic carbonate precursor. The boundaries between the fibrous calcite bands are marked by alignments of microcrystalline aggregates of fluorapatite and/or dolomite. The presence of fluorapatite may indicate a depositional microenvironment eutrophic or rich in microbial communities. Epifluorescence analyses showed bright bands alternated to dark ones, confirming that organic matter remains occur within the studied cements and could have played a significant role in supporting the widespread syndepositional cementation.

High magnification SEM observations on bright epifluorescent bands showed the presence of widespread, more or less spherical bodies ranging in size 100-300 $\mathrm{nm}$. These bodies could represent the relicts of nannobacterial cells.

Keywords: Marine cements; Aragonite-calcite; Biomineralization; Epifluorescence; Nannofossils; Triassic 


\section{Introduction}

A general description of carbonate facies of the Marmolada Platform has been already provided by Russo et al. (2000). The authors recognized the main role and the abundance of striking concentric cements which characterize the outer margin and slope facies. These represent the major constituent of the platform, forming more than $50 \%$ of the rock volume. These peculiar cements were already recognized by Stoppani (1858) in the Triassic buildups of the Western Southern Alps. The author interpreted these structures as encrusting sponges and created the new genus Evinospongia. He also underlined their lithogenetic importance in the Middle Triassic. Evinosponges, also known as "Großoolith" in the Austroalpine Triassic (Schmidegg, 1928), were interpreted as early diagenetic precipitates, modified by fresh-water diagenesis (Brandner and Resch, 1981 and Henrich and Zankl, 1986). Frisia Bruni et al. (1989), in a comprehensive study on evinosponges of the Western Southern Alps, recognized a low-Mg calcite composition, but drew no final conclusion with regard to the origin and primary mineralogy ( $\mathrm{Mg}$ calcite vs. aragonite) of these cements.

Thus "evinosponges" appear to be a phenomenon relatively narrow in geological time and in paleogeographic distribution but they dominated the platforms in which they were present.

Our research is focused on describing the microstructure, mineralogy, geochemistry, and diagenesis of these peculiar cements cropping out in the Marmolada Platform, with the aim to understand the cause of their mineralization. We chose this buildup because it is little affected by dolomitization and shows good outcrops, reasonably easy to sample.

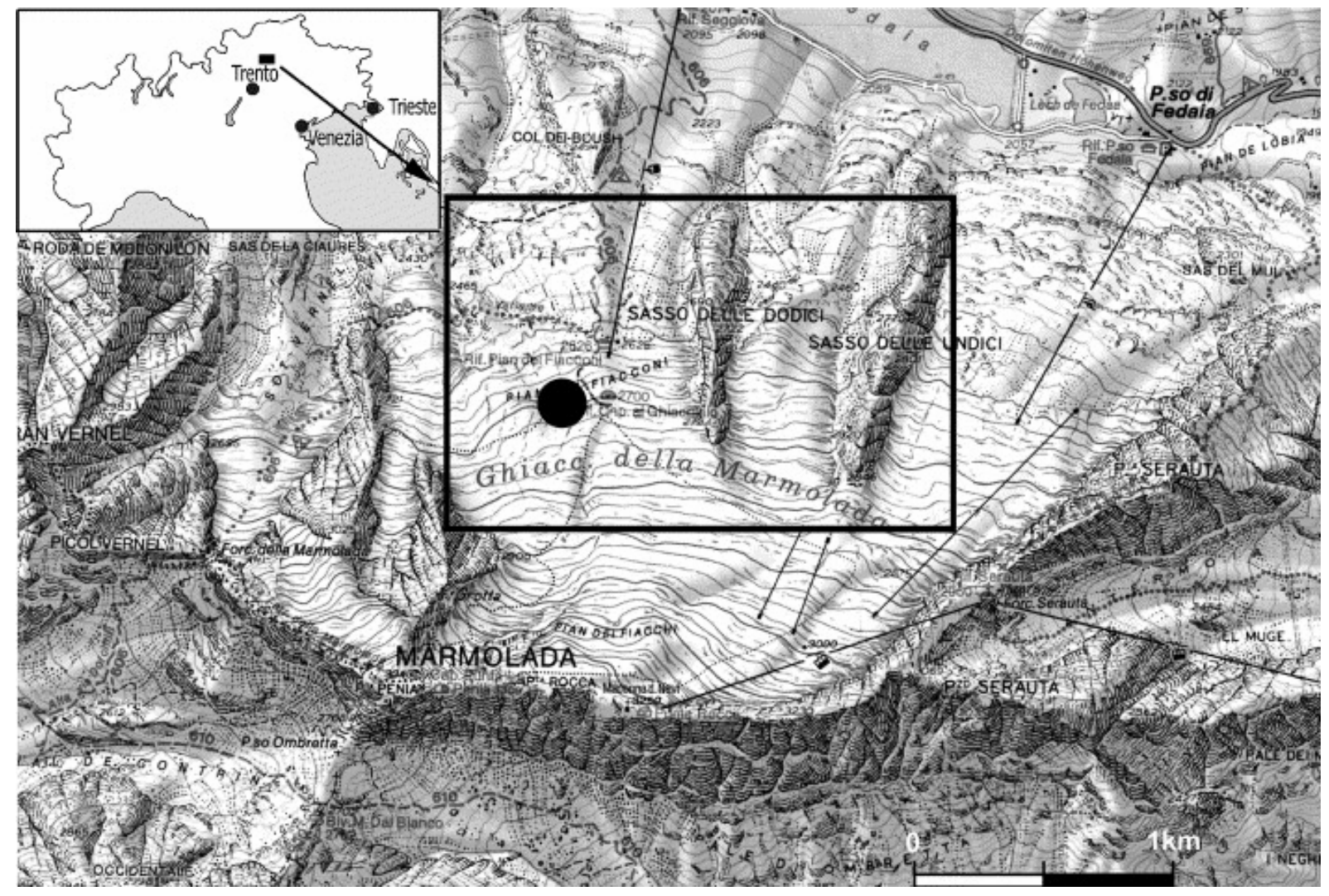

Fig. 1. Location map of the study area, on the northern slope of the Marmolada, Western Dolomites, Italy. The black spot indicates the sampled zone. 


\section{Location}

We collected ten samples of evinosponges on a transect stretched from margin to upper slope setting, on the north-eastern side of the Marmolada Platform, at the Glacier front (Pian dei Fiacconi, between Q 2650 and 2750); here the retreat of the glacier has recently exposed this excellent outcrop (Fig. 1). The ammonoid content indicates an uppermost Anisian age (Secedensis Zone, Brack and Rieber, 1993 and Brack and Rieber, 1996) for these sedimentary rocks.

\section{Marine cements (Evinosponges)}

Outer margin and upper slope of the Marmolada Platform are dominated by a network of globose masses, decimeter in size, which are coated and linked to each other by large amounts of fibrous cements, arranged in concentric bands. These cements form more or less isolated or laterally linked bodies: the evinosponges (Fig. 2a, b). The syndepositional origin of these elements is clearly demonstrated by the fact that they are frequently reworked as clasts in mid to low slope deposits.
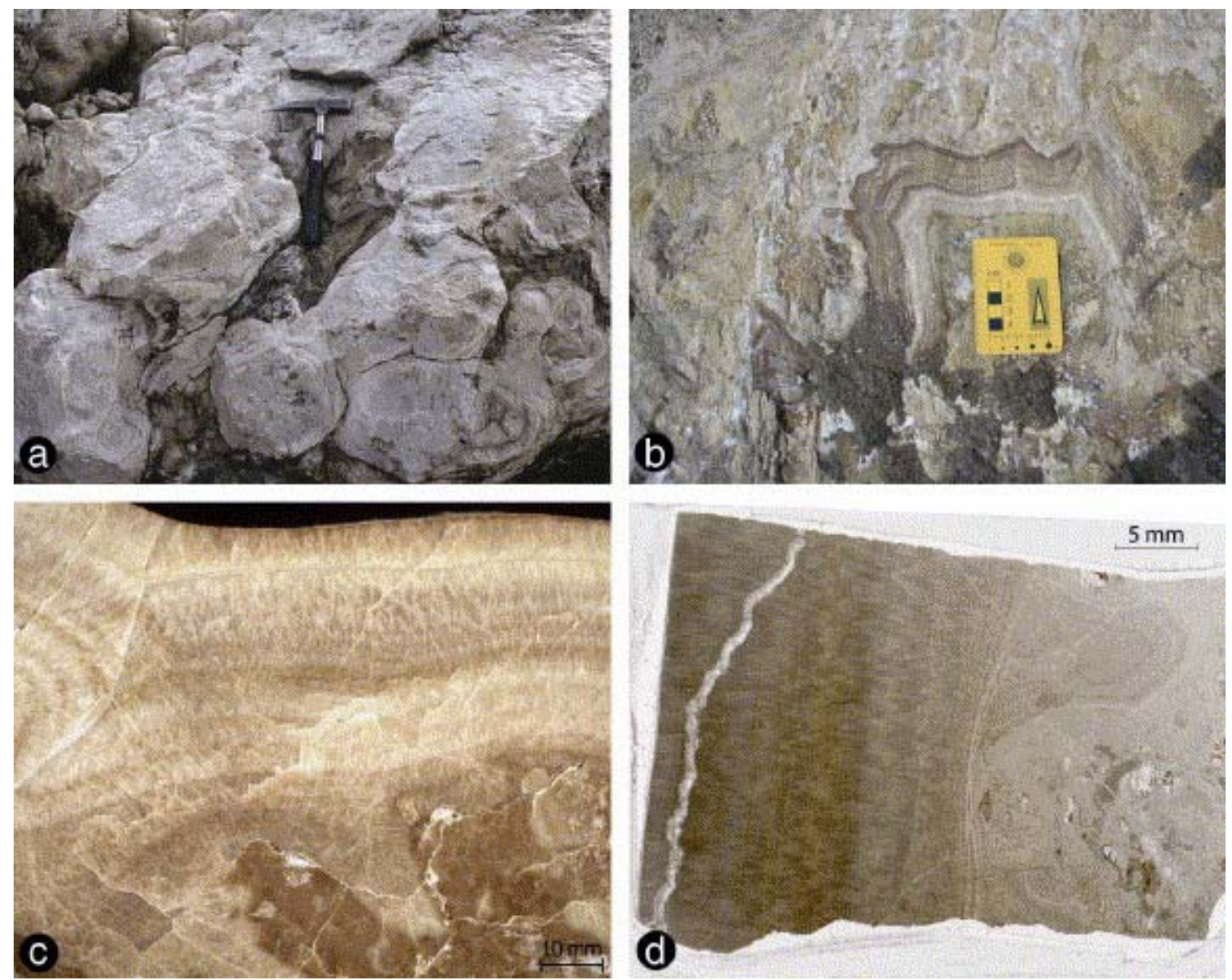

Fig. 2. Fibrous cements, "evinosponges", from the Marmolada Platform, Dolomites, Italy. (a) Field view of a network of globose masses, decimeters in size, which are coated and linked to each other by large amounts of fibrous cements, arranged in concentric bands. (b) Ice polished natural section of evinospongia, with alternating dark and light isopachous layers (Pian dei Fiacconi at about Q $2750 \mathrm{~m}$ ). (c) Isopachous layers of fibrous calcite cement coating a boundstone nucleus, polished surface. Sample BB4. (d) Fibrous cements in thin section. Sample BB4. 
Hand samples show isopachous bands of fibrous calcite of different thickness and colours: light and dark layers alternate with each others, millimeters to centimeters in sizes, and they exhibit a general tendency to increase in thickness from the nucleus toward the periphery (Fig. $2 \mathrm{c}, \mathrm{d})$.

Under the light microscope, the isopachous layers are less easily observable and generally separated by thin lenses which represent discontinuities. They are gaps, subsequently filled by sparry calcite, or by the alignment of small and dark crystalline aggregates (Fig. 3a, c). The calcite fibres show undulose extinction and curved cleavages (Fig. 3c).
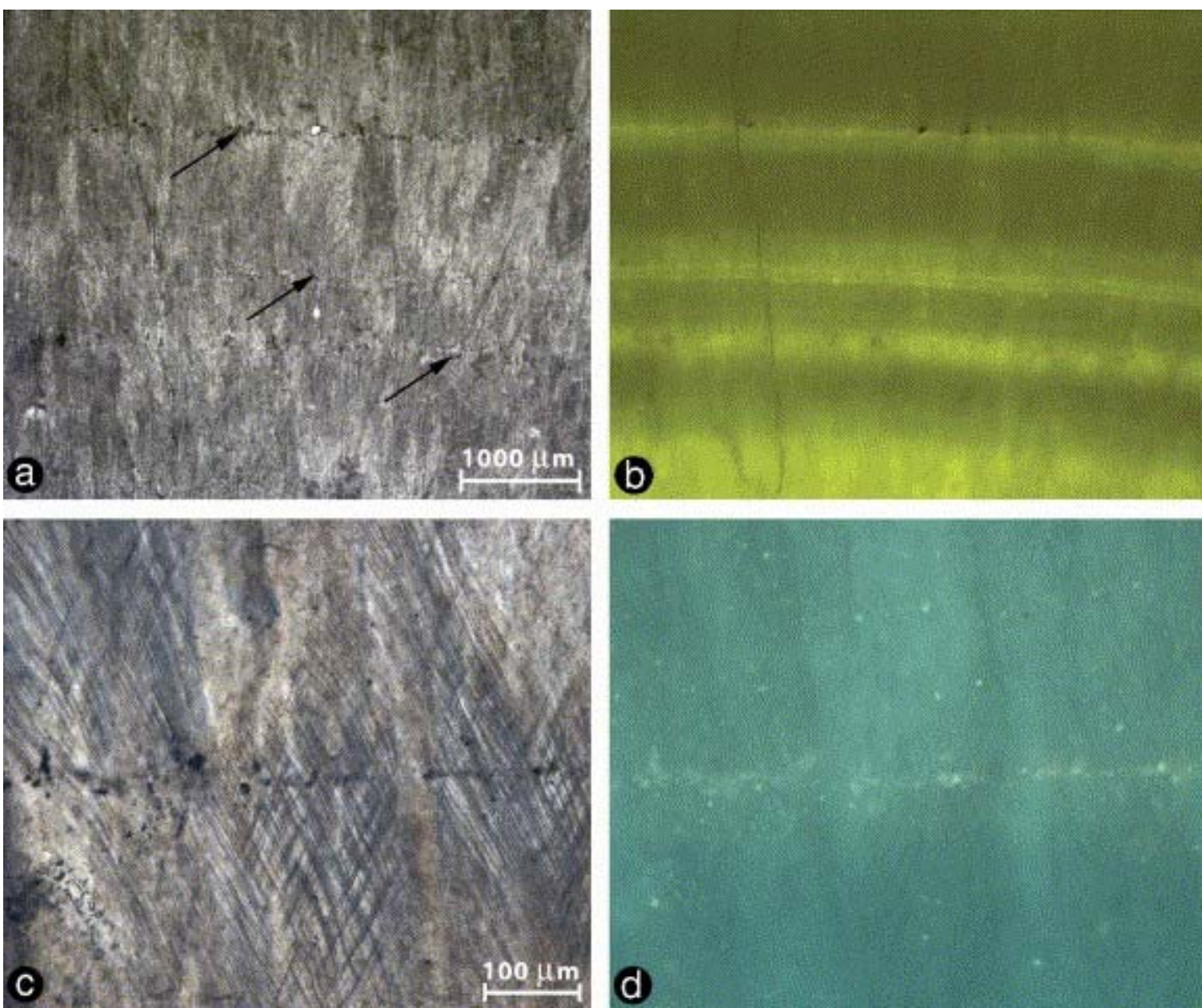

Fig. 3. Isopachous layers of fibrous calcite cements in transmitted and epifluorescent light. (a) Thin section of fibrous cements showing isopachous layers separated by very thin alignment of dark microcrystalline aggregates (black arrows). (b) Epifluorescent image of field (a); note a characteristic alternation of strongly and feebly fluorescent bands. The bands are extremely variable in thickness and the boundaries between isopachous layers are always marked by bright epifluorescence (yellow fluorescence BP 450-490 nm/LP $515 \mathrm{~nm}$ ). (c) Detail of the boundary between two isopachous layers; calcite fibres show curved cleavages. (d) Epifluorescent image of field (c); note the bright fluorescence of the dark microcrystalline aggregate alignment (green fluorescence BP 436/10 $\mathrm{nm} / \mathrm{LP} 470 \mathrm{~nm})$. 


\section{Methods}

Micromorphologies and chemical compositions of cements were determined with a scanning electron microscope, Cambridge 360 linked to an EDAX energy-dispersive X-ray microprobe. The analysed samples were polished with $0.25 \mu \mathrm{m}$ diamond-impregnated surface, then gently etched $(0.05 \% \mathrm{HCl}, 1 \mathrm{~min})$ and carbon coated (ca. $250 \AA)$; the data were corrected with the ZAF algorithm. The working conditions were: voltage $20 \mathrm{kV}$, tilt angle $0^{\circ}$, take-off angle $32.1^{\circ}$. Under these working conditions and with a spot size of $0.1 \mu \mathrm{m}$, the analysed $\mathrm{CaCO}_{3}$ volume measures a few cubic micrometers and the detectability limit for the measured elements ( $\mathrm{Mg}, \mathrm{Al}, \mathrm{Si}, \mathrm{S}, \mathrm{K}, \mathrm{Ca}, \mathrm{Mn}, \mathrm{Fe}, \mathrm{Sr}$, and $\mathrm{Ba})$ is lower than 0.1 wt.\%.

The sections were checked also for fluorescence to reveal the distribution of the organic matter (Dravies and Yurewicz, 1985, Machel et al., 1991, Neuweiler and Reitner, 1995 and Russo et al., 1997). To perform these observations, we used incident light emitted by Hg highpressure vapour bulb attached to Axioplan Imaging II microscope (Zeiss), equipped with high performance wide bandpass filters (BP 436/10 nm/LP $470 \mathrm{~nm}$, no. 488006 , for the green light; BP 450-490 nm/LP $515 \mathrm{~nm}$, no. 488 009, for the yellow light).

\section{Geochemistry}

Minor elements microanalyses were carried out on ten samples. The fibrous calcite cements are characterized by a significant and surprisingly uniform $\mathrm{Mg}$ content (1-3 mol\%). Detectable amounts of Sr, commonly over $1000 \mathrm{ppm}$, sometimes exceeding 10,000 ppm, have been measured (Fig. 4). The strontium geochemical signature in neomorphic calcite could reflect the replacement of an aragonitic carbonate precursor. (e.g. Scherer, 1977, Tucker, 1985 and Sandberg, 1985). The minor element contents and micromorphological fabrics indicate a simple diagenetic history: firstly, evinosponges suffered a neomorphic transformation which lead the metastable aragonite phase to be replaced by stable low-Mg calcite, secondarily, a general aggrading recrystallization.

The boundary between the fibrous calcite bands are marked by discontinuities, often constituted by alignments of microcrystalline aggregates of fluorapatite and/or dolomite (Fig. 3, Fig. 5 and Fig. 6). These boundaries possibly constituted the main ways for diagenetic fluids. The presence of fluorapatite can be considered as indicator of eutrophic water conditions and/or the presence of microbial communities (Rougerie et al., 1997 and Soudry, 2000). 


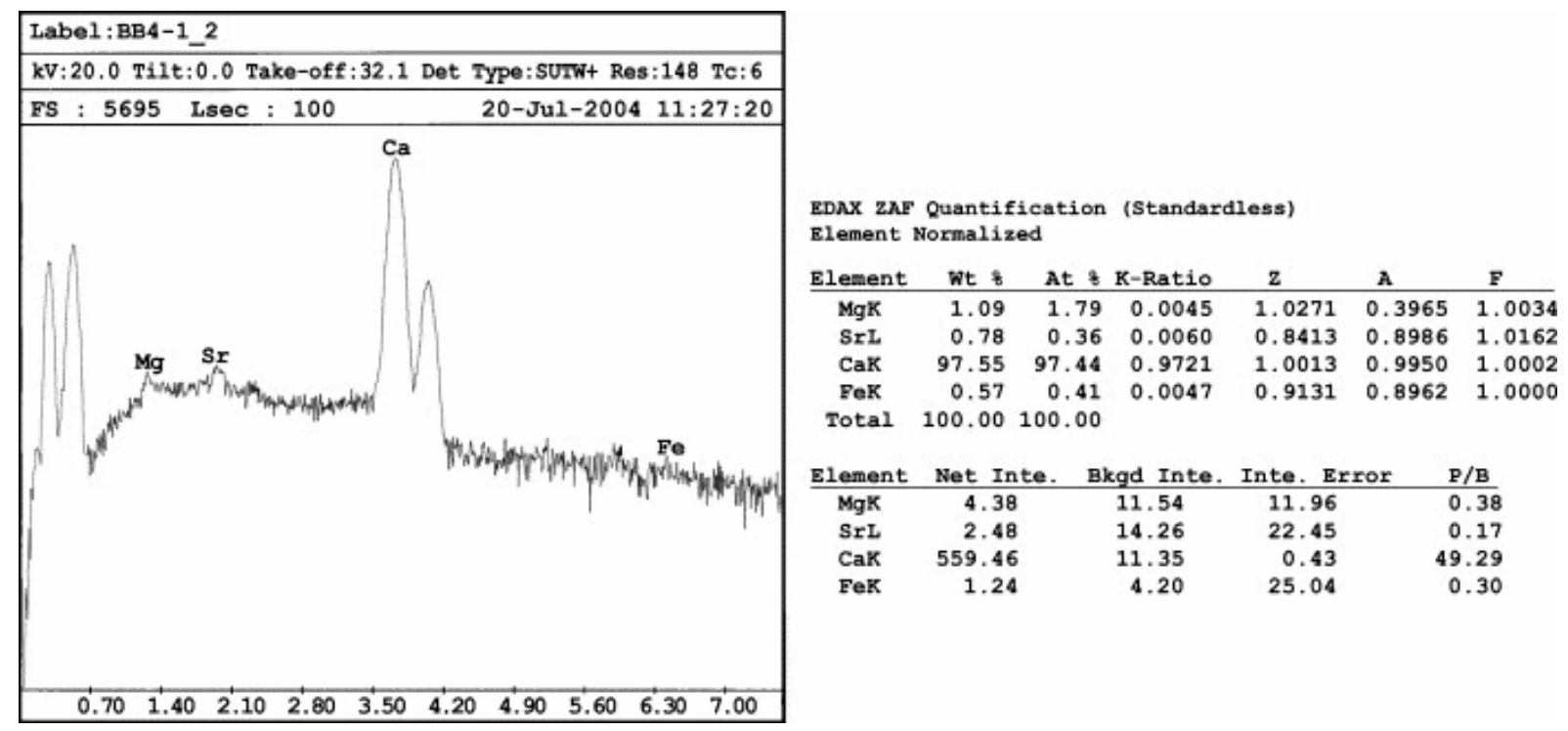

Fig. 4. On the left, X-ray spectrum of a polished surface of fibrous calcite cement; on the right, ZAF quantitative data for the measurable elements. Note the $7800 \mathrm{ppm}$ of $\mathrm{Sr}$ and the $1.8 \mathrm{~mol} \% \mathrm{of} \mathrm{Mg}$.

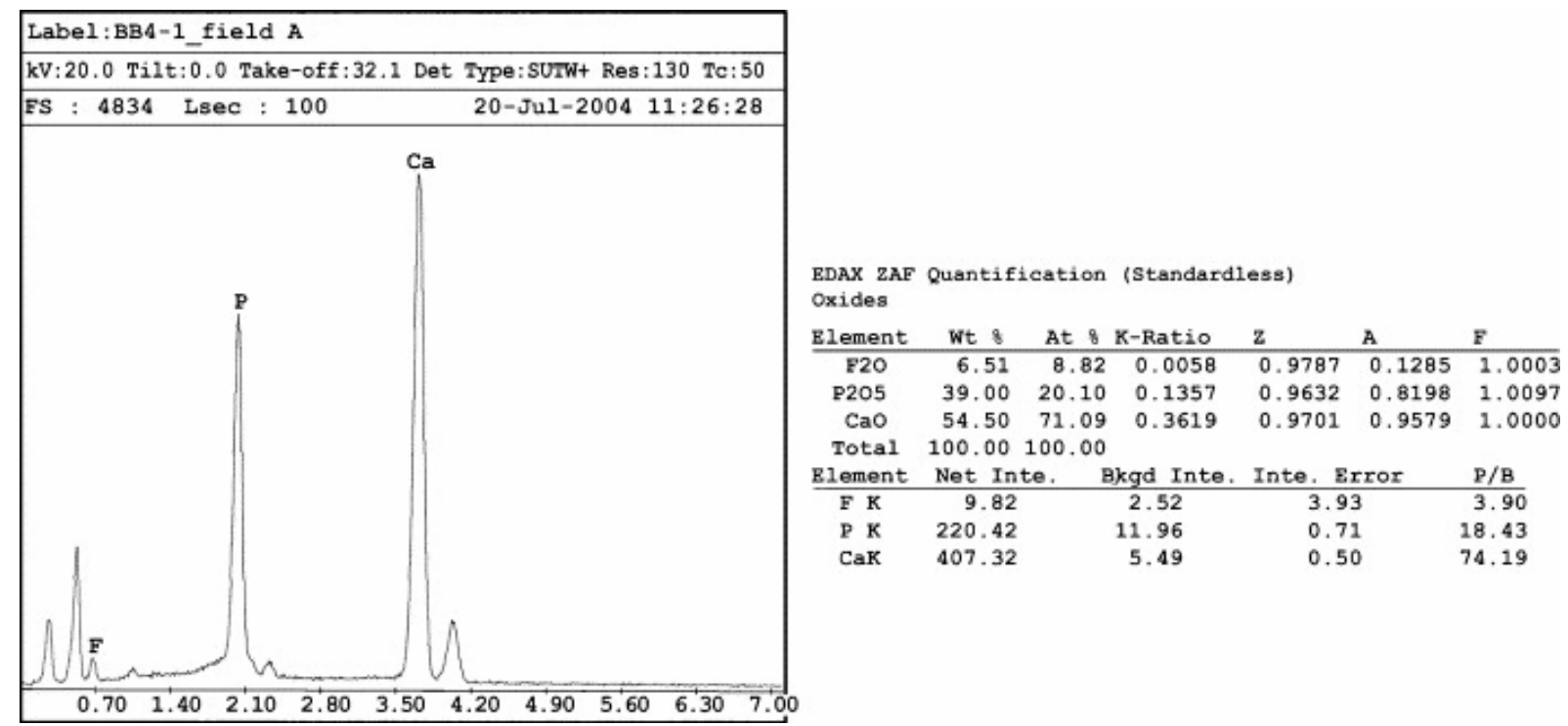

Fig. 5. On the left, X-ray spectrum on a dark microcrystalline aggregate typical of the boundaries between two isopachous calcite layers. On the right, ZAF quantitative data for the measurable oxides; the data fit well with the stoichiometric composition of fluorapatite $\left(55.60 \% \mathrm{CaO}, 42.22 \% \mathrm{P}_{2} \mathrm{O}_{5}\right)$. 

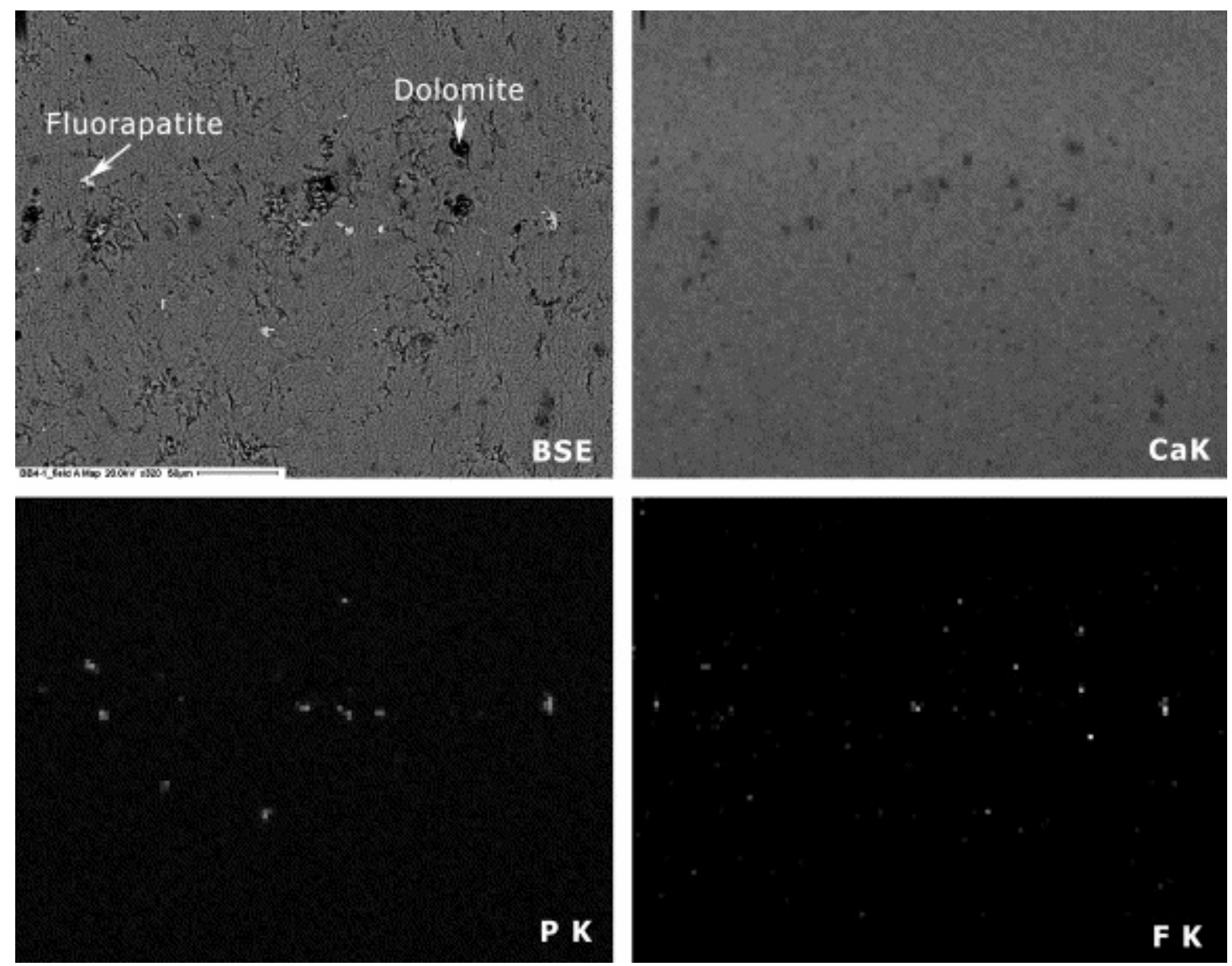

Fig. 6. Backscattered image and X-ray maps of a microarea $(\approx 360 \times 230 \mu \mathrm{m})$ across two isopachous calcite layers. On the upper left the backscattered image, note the alignment of dark (fluorapatite) and bright (dolomite) microcrystalline aggregates. The three X-ray maps ( $\mathrm{Cak}, \mathrm{Pk}$ and $\mathrm{Fk}$ ) confirm the spatial distribution of the recognized minerals (calcite, dolomite, and fluorapatite).

\section{Biomineralization, epifluorescence, organic matter, and nannofossils}

Recent research suggests that bio-induced carbonate precipitation is often more important than the metazoan growth itself. In this study, the understanding of the primary precipitation mechanisms is limited by the recrystallization and by the lack of organic geochemical data.

Many organisms are known to induce carbonate precipitation (e.g. Chafetz, 1986, Simkiss and Wilbur, 1989, Riding, 1991, Addadi and Weiner, 1992, Chafetz and Buczynski, 1992 and Neumeier, 1998), either directly, by biochemical processes, or indirectly, through the changing of the surrounding chemical microenvironments or the trapping of dissolved $\mathrm{Ca}^{2+}$ onto organic templates (Lowenstam and Weiner, 1989). Therefore it is possible to distinguish between "biologically induced" calcification, in which the induction take place in a solution, separated from mineral growth, and "organic matrix-mediated" calcification, which directly controls mineral crystallography. Autotrophic microorganisms can favour carbonate precipitation by increasing $\mathrm{pH}$ through removal of $\mathrm{CO}_{2}$ (Ehrlich, 1996), whereas heterotrophic bacteria spur carbonate formation via ammonification of amino acid, or by nitrate or sulphate 
reduction, processes again leading to an increased pH (Chafetz and Buczynski, 1992, Ehrlich, 1996 and Neumeier, 1998).

Accurate analytical studies on reef cavities and modern atolls (Reitner, 1993, Reitner and Neuweiler, 1995, Reitner et al., 1996, Camoin et al., 1999, Sprachta et al., 2001 and Gautret et al., 2004) have recently corroborated the carbonate biomineralisation model, based on the interaction of acidic organic macromolecules with inorganic compounds (Degens, 1979, Degens et al., 1967, Leadbeater and Riding, 1986, Lowenstam and Weiner, 1989, Mann et al., 1989, Simkiss and Wilbur, 1989, Addadi and Weiner, 1985 and Addadi and Weiner, 1992). The key element of this model consists in a matrix of acidic macromolecules, rich in aspartic and glutamic amino acids, acting as a binding surface for $\mathrm{Ca}^{2+}$ and thus controlling the $\mathrm{CaCO}_{3}$ deposition.

As a result of these processes, the carbonate phases are interlayered with an organic matrix. Such a strict interlayering of calcite and organic matter is documented in this study through epifluorescence observations. Epifluorescence microscopy on polished thin sections reveals the distribution and concentration of potential chromophores, such as aromatic compounds, humic and fulvic acids (Vandenbroucke et al., 1985, Bertrand et al., 1986 and Ramseyer et al., 1997). However, the interpretation of the fluorescence of sedimentary organic matter cannot be based on a direct correlation between preserved aromatic compounds and intensity. In fact a range of chromophores exits with different fluorescences and there are also secondary absorbing effects controlled by other factors (Bertrand et al., 1986).

Residual organic matter as well as $\mathrm{Mn}^{2+}$ appear to be the most abundant and important activators of luminescence in natural calcite and dolomite (Lumb, 1978, van Guzel, 1979, Dravies and Yurewicz, 1985 and Machel et al., 1991). Organically activated luminescence seems to be caused mainly by aromatic and certain conjugated organic molecules (Lumb, 1978).

Cuif et al. (1990), Müller-Wille and Reitner (1993), Reitner and Neuweiler (1995), and Russo et al., 1997 and Russo et al., 2000 used fluorescence microscopy to check the presence of residual organic matter.

Uncovered thin sections of evinosponge samples were checked for epifluorescence. The cements are characterized by an alternation of strongly and feebly fluorescent bands, both with yellow (Fig. 3b) or green light (Fig. 3d). The bands are extremely variable in thickness and the boundaries between isopachous layers are always marked by bright epifluorescence (Fig. 3b, d).

Epifluorescence data indicate a general and widespread presence of organic matter, preferably concentrated along parallel bands.

SEM observations at high-magnification on these strongly epifluorescent bands revealed the presence of more or less spherical bodies ranging in size 100-300 nm (Fig. 7a). These objects could represent the relicts of nannobacterial cells which may have played a significant role in supporting the widespread syndepositional cementation, with a possible mechanism analogous to that of microbialite deposition. 

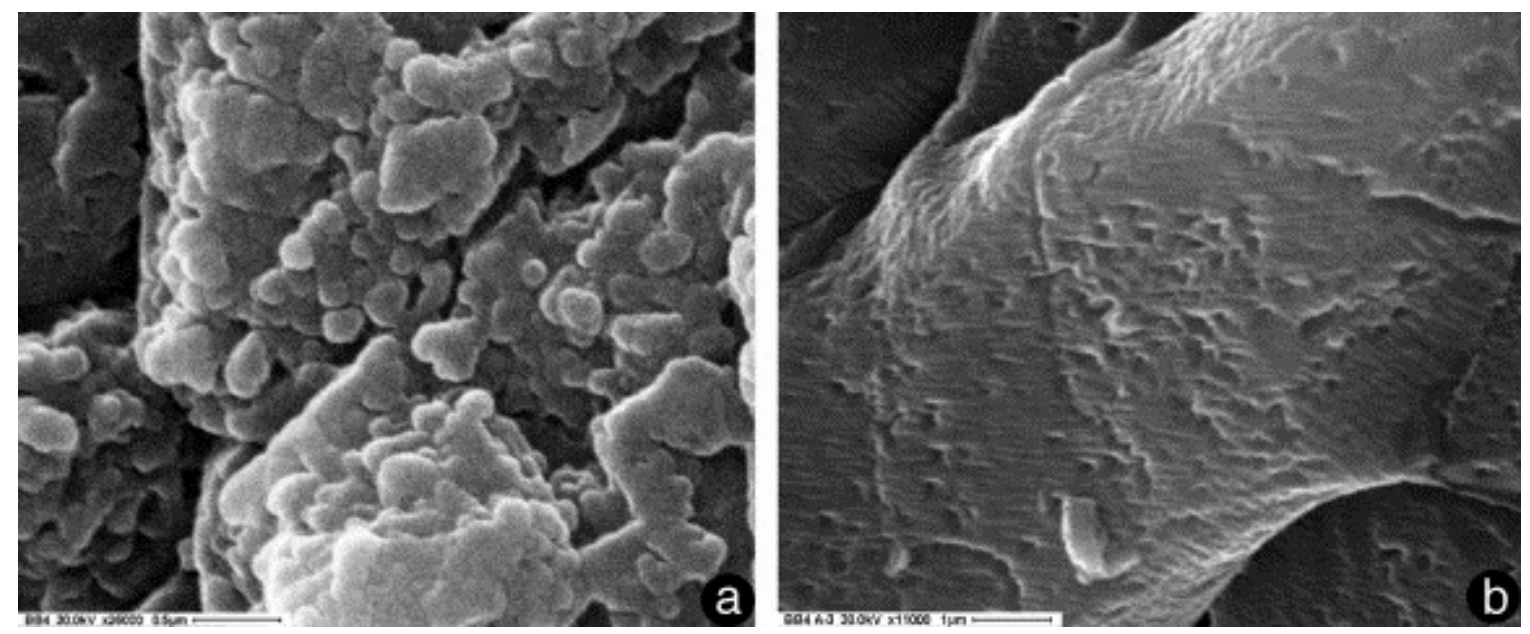

Fig. 7. High magnification SEM secondary electron images of fibrous cements (evinosponges). (a) Observation on strongly epifluorescent bands with the presence of widespread, more or less spherical bodies ranging in size from 100 to $300 \mathrm{~nm}$; these bodies may represent the relicts of nanobacterial cells. (b) Only crystal micromorphology and traces of the bent cleavages are visible in the feeble fluorescent areas.

\section{Nannofossils or artifacts?}

Investigations of micromorphologies in various carbonates have shown nanometer-scale spherical bodies in the 25-300 nm range (Folk, 1993, Folk, 1999, Pedone and Folk, 1996, Vasconcelos and McKenzie, 1997, Camoin et al., 1999, Sprachta et al., 2001 and Gautret et al., 2004). The nature of such bodies, visible with scanning or transmission electron microscopes (SEM or TEM) at high magnification, is still debated and controversial.

Many authors assumed for these objects a biological origin and interpreted them as remains of nannobacteria/nannofossils (Folk, 1993, Folk, 1999 and McKay et al., 1996). In addition, similar spherical bodies have also been produced in laboratory experiments (Buczynski and Chafetz, 1991, Folk, 1993, Vasconcelos and McKenzie, 1997 and Chafetz and Buczynski, 1992). In contrast, Reitner et al. (1995) considers such precipitates as by-products of initial calcification of extracellular polymeric substances (EPS).

Recently remarkable papers have been developed on recent and Holocene microbialites, their environmental significance and biochemical controls (Camoin et al., 1999, Sprachta et al., 2001 and Gautret et al., 2004). The authors observed that the finest carbonate precipitates of the microbialites are constituted by rounded bodies $0.1-$ to $0.2-\mu \mathrm{m}$-sized, which represent the basic constructional elements of the automicrite. They maintained that both biomineralization and organomineralization (sensu Trichet and Défarge, 1995) were responsible for their formation and distribution and that their size and shape are reminiscent of calcified bacterial remains.

A similar relationship between organic matter decomposition, nannobacteria and carbonate precipitation has been reported by Pedone and Folk (1996) for the formation of micrometersized aragonite cements in modern stromatolites of the Great Salt Lake (Utah).

A totally different interpretation considers these small problematic carbonate objects as artifacts (Bradley et al., 1997 and Kirkland et al., 1999). Kirkland et al. (1999) performed numerous calcite precipitation experiments and demonstrated that nanometer-scale objects 
can have inorganic origins. They also demonstrated the possibility that acid etching of calcite crystals could produce features similar to nannobacteria.

We paid particular attention to avoid the introduction of investigator product artifacts. First, we used carbon instead of gold for the conductive layer, which allowed more reliable quantitative EDS microanalyses. Second, nannofossils have been observed on strongly epifluorescent bands (Fig. 7a), while areas with feeble epifluorescence showed only crystal micromorphology and traces of the bent cleavages (Fig. 7b), suggesting that the detected small bodies have a biological origin.

In conclusion, we recognize in these marine cements (evinosponges) the presence of organic matter remains in alternated layers where the carbonate phase appears to be organized in nanometer-scale spherical bodies, very similar to those observed in the microbialites as basic constructional elements of the carbonate precipitates (Camoin et al., 1999, Sprachta et al., 2001 and Gautret et al., 2004). This fact suggests the possibility that evinosponges precipitated with a mechanism similar to that of microbialites.

\section{Conclusions}

The margin and upper slope of the Marmolada Platform (Upper Anisian-Ladinian) are dominated by peculiar carbonate cements known as "evinosponges". They are decimetersized globular structures formed by isopachous fibrous layers enveloping a boundstone nucleus.

Evinosponges are constituted of low Mg-calcite (1-3 mol\%). Morphological fabric and a discrete amount of $\mathrm{Sr}$, sometimes exceeding $10,000 \mathrm{ppm}$, suggest a marine phreatic aragonitic precursor. The boundaries between adjacent isopachous layers are often marked by the alignment of microaggregates of dolomite and fluroapatite crystals. The presence of fluorapatite can be considered as indicator of eutrophic water conditions and/or the presence of microbial communities. These boundaries possibly constituted the main ways for diagenetic fluids.

Geochemistry data indicate a simple diagenetic history: evinosponges suffered a neomorphic transformation (aragonite-calcite) and, later, a general aggrading recrystallization.

Epifluorescence analyses revealed an irregular alternation of bright and dark bands of different thicknesses, which indicate the presence of organic matter remains in concentric bands. SEM observations at high magnifications on the bright epifluorescent bands, rich in organic matter remains, showed that the carbonate phase appear to be organized in spherical bodies, submicrometer-sized $(100-300 \mathrm{~nm})$. We interpreted these objects as nannofossils, suggesting that marine cements (evinosponges) like the microbialites could have been formed via organic matter and/or microbial mediation.

The presence of cyclic alignment of microcrystalline aggregates of fluorapatite, which corresponds to the bright fluorescent bands, indicates periods of high nutrient supply to the marine environment. These eutrophic water conditions could have facilitated the growth of these peculiar cements, which characterize the carbonate platforms in the Western Tethys during a short interval of geological time and space. 


\section{Acknowledgements}

The manuscript has benefited greatly from critical comments and suggestions by Henry Chafetz and an anonymous reviewer. The authors wish to thank the Editor, Gilbert Camoin, for his valuable comments, which certainly improved the paper.

This is a contribution to the Research Project "Characterization and role of organic and inorganic components in recent and fossil carbonate biomineralizations" financed by the MIUR (FIRB 2001 and PRIN 2004 founds) (F. Russo coordinator).

\section{References}

Addadi and Weiner, 1985 L. Addadi and S. Weiner, Interactions between acidic proteins and crystals: stereochemical requirements in biomineralization, Proc. Natl. Acad. Sci. U. S. A. 82 (1985), pp. 4110-4114.

Addadi and Weiner, 1992 L. Addadi and S. Weiner, Kontroll-und Designprinzipien bei der Biomineralisation, Angew. Chem. 104 (1992), pp. 159-176 (Weinheim).

Bertrand et al., 1986 P. Bertrand, J.L. Pittion and C. Bernaud, Fluorescence of sedimentary organic matter in relation to its chemical composition, Org. Geochem. 10 (1986), pp. 641647.

Brack and Rieber, 1993 P. Brack and H. Rieber, Towards a better definition of the Anisian/Ladinian boundary: new biostratigraphic data and correlation of boundary sections from Southern Alps, Eclogae Geol. Helv. 86 (1993), pp. 415-527.

Brack and Rieber, 1996 P. Brack and H. Rieber, The new "high resolution Middle Triassic ammonoid standard scale" proposed by Triassic researchers from Padova - a discussion of the Anisian/Ladinian boundary interval, Albertiana 17 (1996), pp. 42-50.

Bradley et al., 1997 J.P. Bradley, R.P. Harvey and H.Y. McSween Jr., No "nannofossils" in Martian meteorite, Nature 390 (1997) (454 pp.).

Brandner and Resch, 1981 R. Brandner and W. Resch, Reef development in the Middle Triassic (Ladinian and Cordevolian) of the Northern Limestones Alps near Innsbruck, Austria. In: D.F. Toomey, Editor, European Fossil Reefs Models, Soc. Econ. Paleont. Min. Spec. Publ. vol. 30 (1981), pp. 203-231.

Buczynski and Chafetz, 1991 C. Buczynski and H.S. Chafetz, Habit of bacterially induced precipitates of calcium carbonate and the influence of medium viscosity on mineralogy, $J$. Sediment. Petrol. 61 (1991), pp. 226-233.

Camoin et al., 1999 G. Camoin, P. Gautret, L.F. Montaggioni and G. Cabioch, Nature and environmental significance of microbialites in Quaternary reefs: the Tahiti paradox, Sediment. Geol. 126 (1999), pp. 271-304.

Chafetz, 1986 H.S. Chafetz, Marine peloids: a product of bacterially induced precipitation of calcite, J. Sediment. Petrol. 56 (1986), pp. 812-817. 
Chafetz and Buczynski, 1992 H.S. Chafetz and C. Buczynski, Bacterially induced lithification of microbial mats, Palaios 7 (1992), pp. 277-293.

Cuif et al., 1990 J.P. Cuif, P. Gautret, G.F. Laghi, A. Mastandrea, B. Pradier and F. Russo, Recherche sur la fluorescence UV du squelette aspiculaire chez les demosponges calcitiques triassiques, Geobios 23 (1990), pp. 21-31.

Degens, 1979 E.T. Degens, Why do organisms calcify?, Chem. Geol. 25 (1979), pp. 257-269.

Degens et al., 1967 E.T. Degens, F.G. Carey and D.W. Spencer, Amino-acids and aminosugars in calcified tissues of portunid crabs, Nature 216 (1967), pp. 601-603 (London).

Dravies and Yurewicz, 1985 J.J. Dravies and D.A. Yurewicz, Enhanced carbonate petrography using fluorescence microscopy, J. Sediment. Petrol. 55 (1985), pp. 795-804.

Ehrlich, 1996 H.L. Ehrlich, Geomicrobiology (3rd ed.), Dekker, New York (1996) 393 pp..

Folk, 1993 R.L. Folk, SEM imaging of bacteria and nannobacteria in carbonate desiments and rocks, J. Sediment. Petrol. 63 (1993), pp. 990-999.

Folk, 1999 R.L. Folk, Nannobacteria and the precipitation of carbonate in unusual environments, Sediment. Geol. 126 (1999), pp. 47-55.

Frisia Bruni et al., 1989 S. Frisia Bruni, F. Jadoul and H. Weissert, Evinosponges in the Triassic Esino Limestone (Southern Alps): documentation of early lithification and late diagenetic overprint, Sedimentology 36 (1989), pp. 685-699 (Amsterdam).

Gautret et al., 2004 P. Gautret, G. Camoin, S. Golubic and S. Sprachta, Biochemical control of calcium carbonate precipitation in modern lagoonal microbialites, Tikehau Atoll, French Polynesia, J. Sediment. Res. 74 (2004), pp. 462-478.

Henrich and Zankl, 1986 H. Henrich and H. Zankl, Diagenesis of Upper Triassic Wetterstein reefs of the Bavarian Alps. In: J.H. Schroeder and B.H. Purser, Editors, Reef Diagenesis, Springer-Verlag, Berlin (1986), pp. 245-268.

Kirkland et al., 1999 B.L. Kirkland, F.L. Lynch, M.A. Rahnis, R.L. Folk, I.J. Molineux and R.J.C. McLean, Alternative origins for nannobacteria-like objects in calcite, Geology 27 (1999), pp. 347-350.

Leadbeater and Riding, 1986 B.S.C. Leadbeater and R. Riding, Biomineralization in lower plants and animals, The Systematics Association Spec vol. 30, Clarendon Press, Oxford (1986) $398 \mathrm{pp}$.

Lowenstam and Weiner, 1989 H.A. Lowenstam and S. Weiner, On Biomineralization, Oxford Univ. Press, Oxford (1989) 324 pp..

Lumb, 1978 M.D. Lumb, Luminescence Spectroscopy, Academy Press, London (1978) 380 pp.. 
Machel et al., 1991 H.G. Machel, R.A. Mason, A.N. Mariano and A. Mucci, Causes and emission of luminescence in calcite and dolomite. In: C.E. Barker and O.C. Kopp, Editors, Luminescence Microscopy and Spectroscopy: Qualitative and Quantitative Applications, Soc. Econ. Paleont. Miner. Short Course vol. 25, Tulsa (1991), pp. 9-25.

Mann et al., 1989 S. Mann, J. Webb and R.J.P. Williams, Biomineralization, VCH, Weinheim (1989) $541 \mathrm{pp}$.

McKay et al., 1996 D.S. McKay, E.K. Gibson, K.L. Thomas-Keprta, L.H. Vali, C.S. Romanek, S.J. Clemett, Z.D.F. Chillier, C.R. Maechling and R.N. Zare, Search for past life on Mars: possible relic biogenic activity in Martian meteorite ALH84001, Science 273 (1996), p. 924.

Müller-Wille and Reitner, 1993 S. Müller-Wille and J. Reitner, Palaeobiological reconstructions of selected sphinctozoan sponges from the Cassian Beds (Lower Carnian) of the Dolomites (Northern Italy), Berl. Geowiss. Abh., E Palaobiol. 9 (1993), pp. 253-281.

Neumeier, 1998 U. Neumeier, Le role de l'activité microbienne dans la cimentation précoce des beachrocks (sédiments intertidaux), Terre Environ. 12 (1998), pp. 1-183 (Genève).

Neuweiler and Reitner, 1995 F. Neuweiler and J. Reitner, Epifluorescence-microscopy of selected automicrites from lower Carnian Cipit - boulders of the Cassian formation (Seeland Alpe, Dolomites). In: J. Reitner and F. Neuweiler, Editors, Mud Mounds: A Polygenetic Spectrum of Fine-grained Carbonate Buildups, Facies vol. 32 (1995), pp. 26-28 Erlangen.

Pedone and Folk, 1996 V.A. Pedone and R.L. Folk, Formation of aragonite cement by nanobacteria in the Great Salt Lake, Utah, Geology 24 (1996), pp. 763-765.

Ramseyer et al., 1997 K. Ramseyer, T.M. Miano, V. d'Orazio, A. Wildberger, T. Wagner and J. Geister, Nature and origin of organic matter in carbonates from speleothems, marine cements and coral skeleton, Org. Geochem. 26 (1997), pp. 361-378.

Reitner, 1993 J. Reitner, Modern cryptic microbialite/metazoan facies from Lizard Island (Great Barrir Reef, Australia): formation and concepts, Facies 29 (1993), pp. 3-40 (Erlangen).

Reitner and Neuweiler, 1995 J. Reitner and F. Neuweiler, Supposed principal controlling factors of rigid micrite buildups. In: J. Reitner and F. Neuweiler, Editors, Mud Mounds: A Polygenetic Spectrum of Fine-grained Carbonate Buildups, Facies vol. 32 (1995), pp. 4-17 Erlangen.

Reitner et al., 1995 J. Reitner, P. Gautret, F. Marin and F. Neuweiler, Automicrites in a modern marine microbialite. Formation model via organic matrices (Lizard Island, Great Barrier Reef, Australia), Bull. Inst. Océanogr. Monaco, Special Number 14 (1995), pp. $237-$ 263.

Reitner et al., 1996 J. Reitner, J. Paul, G. Arp and D. Hause-Reitner, Lake Thetis domal microbialites - a complex framework of calcified biofilms and organomicrites (Cervantes, Western Australia). In: J. Reitner, F. Neuweiler and F. Gunkel, Editors, Global and Regional 
Controls on Biogenic Sedimentation: I. Reef Evolution, Res. Reports. Göttinger Arb. Geol. Paläont. Sb 2, Göttingen (1996), pp. 85-89.

Riding, 1991 R. Riding, Classification of microbial carbonates. In: R. Riding, Editor, Calcareous Algae and Stromatolites, Springer-Verlag, Berlin (1991), pp. 21-51.

Rougerie et al., 1997 F. Rougerie, C. Jehl and J. Trichet, Phosphorus pathways in atolls: interstitial nutrient pool, cyanobacterial accumulation and Carbonate-Fluoro-Apatite (CFA) precipitation, Mar. Geol. 139 (1997), pp. 201-217.

Russo et al., 1997 F. Russo, C. Neri, A. Mastandrea and A. Baracca, The Mud Mound nature of the Cassian Platform margins of the Dolomites. A case history: the Cipit boulders from Punta Grohmann (Sasso Piatto Massif, Northern Italy), Facies 36 (1997), pp. 25-36 (Erlangen).

Russo et al., 2000 F. Russo, A. Mastandrea, C. Stefani and C. Neri, Carbonate facies dominated by syndepositional cements: a key component of Middle Triassic platforms. The Marmolada case history (Dolomites, Italy), Facies 42 (2000), pp. 211-226 (Erlangen).

Sandberg, 1985 P. Sandberg, Aragonite cements and their occurrence in ancient limestone. In: N. Schneidermann and P.M. Harris, Editors, Carbonate Cements, Soc. Econ. Paleont. Miner. Spec. Publ. vol. 36 (1985), pp. 33-57.

Scherer, 1977 M. Scherer, Preservation, alteration and multiple cementation of aragonite skeleton from the Cassian Beds (U. Triassic, southern Alps). Petrographic and geochemical evidence, N. Jb. Geol.Paläont., Abh. 154/2 (1977), pp. 213-262.

Schmidegg, 1928 O. Schmidegg, Über geregelte Wachstumsgefüge, Jb. Geol. Bundesanstalt 78 (1928), pp. 1-52.

Simkiss and Wilbur, 1989 K. Simkiss and K.M. Wilbur, Biomineralization, Cell Biology and Mineral Deposition, Academic Press, San Diego (1989) 337 pp..

Soudry, 2000 D. Soudry, Microbial phosphate sediments. In: R. Riding and S.M. Awramik, Editors, Microbial Sediments, Springer-Verlag, Berlin (2000), pp. 127-136.

Sprachta et al., 2001 S. Sprachta, G. Camoin, S. Golubic and Th. Le Campion, Microbialites in a modern lagoonal environment: nature and distribution, Tikehau atoll (French Polynesia), Palaeogeogr. Palaeoclimat. Palaeoecol. 175 (2001), pp. 103-124.

Stoppani, 1858 A. Stoppani, Les petrifications d'Esino ou description des fossiles appartenants au depot superieur des environs d'Esino en Lombardie, Paleont. Lombarde vol. 1, Milano (1858) 360 pp..

Trichet and Défarge, 1995 J. Trichet and C. Défarge, Non-biologically supported organomineralization, Bull. Inst. Océanogr. Monaco Special Number 14 (1995), pp. 203236.

Tucker, 1985 M.E. Tucker, Calcitized aragonite ooids and cements from the Late Precambrian of southern Norway, Sediment. Geol. 43 (1985), pp. 67-84. 
Vandenbroucke et al., 1985 M. Vandenbroucke, R. Pelet and Y. Debyser, Geochemistry of humic substances in marine sediments. In: G.R. Aiken, D.M. Mcknight, R.L. Wershaw and P. MacCarthy, Editors, Humic Substances in Soil, Sediment, and Water, Wiley, New York (1985), pp. 249-273.

van Guzel, 1979 P. van Guzel, Manual of the techniques and some geological applications of fluorescence microscopy, Am. Assoc. Strat. Palynologists, Dallas (1979) 55 pp..

Vasconcelos and McKenzie, 1997 C. Vasconcelos and J.A. McKenzie, Microbial mediation of modern dolomite precipitation and diagenesis under anoxic condition (Lagoa Vermelha, Rio de Janeiro, Brazil), J. Sediment. Res. 67 (1997), pp. 378-390 